\title{
NURSING EDUCATION AS ADULT EDUCATION a philosophical standpoint
}

\section{V.J. PINKNEY-ATKINSON BSc (Nursing), RN, RM, D. NEd \\ Director: Public and Professional Relations, BBDO Health and Medical Communications}

\section{OPSOMMING}

Die outeur neem die standpunt in dat indien verpleegkundiges in Suid-Afrika die uitdagings van die toekoms te bowe will kom verandering in fundamentele beskouings cor verpleegonderwys noodsaaklik is. Een van die beskouings wat moet verander is die siening dat basiese verpleegonderwys pedagogie eerder as andragogie is - die studentverpleegkundige moet beskou word as ' $n$ volwasse leerder wat betrokke is by volwasse onderwys.

Dit sal nuwe moontlikhede vir selfgerigte en leerdergesentreerde onderrig skep. Die vrugte hiervan sal wees goeie pasiëntsorg deur verpleegkundiges vir wie leer 'n voortdurende proses is.

\section{DEFINING ADULT EDUCATION}

There are probably as many definitions of adult education as there are authors on the subject. In most cases the definition reflects the particular bias of the author. In its opening statement on the subject, The Encyclopedia for Educational Research (1 p.30) notes that adult education may be defined in many ways.

These many definitions may range from very broad to very narrow perspectives. The most frequently mentioned characteristics of adult education in the literature were reviewed in one study. These are that adult education is characterised as being:

- voluntary on the part of the learner;

- part-time;

- under organised auspices;

- for persons beyond school age (1 p. 30).

Each characteristic has its own problems, depending upon one's vantage point. The voluntary nature of adult education is probably the least questionable.

When the term adult education was first used, it was applied to the educational activities associated with what is today known as remedial adult education. Its target pop- ulation was those adults who had received little or no basic school education. Later, other meanings were applied. Each reflected the needs of the individual adults participating in the education process.

One such restricting application emphasises only the organised activities and programmes concerned with the education of adults (2 p.15). In this sense it embraces the whole complex of educational institutions, professional and semi-professional bodies and voluntary organisations which organise adult education programmes. It ignores the informal unorganised education undertaken by individual adults who perceive their own needs.

In its broadest application, the term adult education may be defined as a means of social adjustment and an educational movement (1 p. 30). This allows us to come to grips with the very essence of its nature. When viewed in this way, education for adults is a means of adjusting to a changing world and is a by-product of the scientific age. Therefore, as an educational movement it is based on the needs for social adjustment by Modern Man.

Margaret Mead (2 p. 68) put it succinctly when she noted:

A great deal of what needs to be taught to adults today was unknown when they were young. Continuing education throughout life has become a necessity in almost every field, from housekeeping to atomic physics ... In the advanced countries the impact of change is emphasising the need for continuing education throughout life and forcing a fresh assessment of the whole educational system in the light of this concept.

This quotation serves to highlight the philosophy underlying adult education. Education is a life-long process which does not halt at the end of one's schooling. This is especially true of Man in the twentieth century. In order to adjust to his rapidly changing environment he must constantly learn new skills and gain knowledge. Adult education should then be viewed as one part of the process of education.

\section{EDUCATION A CONTINUOUS PROCESS}

The first of three principles ( 3 p. 58 ) that any adult education programme should bear in mind is that education is not complete when a man or a woman leaves school and goes to work. The second is that it is a continuous process which goes on throughout life and affects all aspects of life. This includes the growth of the individual, with all facets of his development: aesthetic, intellectual, physical and vocational.

The third principle of adult education is that most adults can and want to learn, but their capacity to study is lost through disuse. Therefore, it is important to provide opportunities for the educational process to continue uninterrupted so that their learning skills are not lost.

The preceding discussion has brought our attention to the fact that adult education is merely part of the continuum of education. It brings in to question the present education system which does not emphasise sufficiently to young people that they have not com- 
pleted their education when they leave school or even finish vocational training. They must be taught, as part of this early education, that they are being prepared for further life-long study.

If education is viewed as a continuous process throughout life, there is a need not only for a change in approach and methods in education, but also for a complete re-appraisal of methods, approaches and curricula in primary, secondary and tertiary education. (2 p. 68).

From this vantage point it becomes less easy to distinguish adult and child education. The division lies in the present education system rather than the process of education. The methods of adult education then become the methods of education for children.

Having established this philosophical viewpoint of adult education it must be linked to nursing education. Nursing education suffers from the same erroneous division into child and adult education.

\section{NURSING EDUCATION AS ADULT EDUCATION}

Basic nursing education lays the foundations for the effective practice of nursing and a basis for advanced nursing education (4 p. 6). In most cases basic nursing has as its target population students who are relatively recent schoolleavers, the majority of whom are below the age of 21 years and therefore legally minors (5 p. 10).

This view is made more explicit in the following quotation of a statement made by a nurse educator ( 6 p. 139).:

Basic nursing education is concerned with the instruction of the adolescent, that is, it is part of pedagogy, as it deals with the adolescent on the way to adulthood, and specially to professional adulthood. It is education after the child has completed the period of secondary education and therefore falls into the category of tertiary education.

The student nurses who are the consumers of basic nursing education are therefore considered to be less than adults from both a legal and from a nurse educator standpoint. At best they are considered adolescents; at worst, children.

Yet in the practical ward situation student nurses are required to take very adult responsibilities for patient care. These responsibilities may involve, in the most extreme cases, life and death decisions. During their entire lives some adults may never be asked to make similar decisions. In their private lives student nurses are able to vote, drive, marry and have children during this same period. All of which are very adult responsibilities.

The language used in the preceding paragraphs may be considered by some to be rather emotive, but it serves to highlight the ambiguous situation in which basic nursing education places both its student nurses and its educators. It certainly would be more congruent with the patient care expected of student nurses to consider them as adults.

Nursing, like other systems in society, is being subjected to the same pressures of a rapidly developing technological society.

In the next decade nursing will be faced with some of its greatest and most exciting challenges. With the trend towards mass medical care and the changing patterns of health services, the nurse of tomorrow will have to accept unprecedented responsibilities. Minor modifications of existing nursing systems will be inadequate to meet new situations and demands in a rapidly changing society. Fundamental rethinking will be necessary. (7 p. 7)

A fundamental rethinking of nursing education would, it is believed, consider student nurses undergoing basic nursing education as adults. It would certainly relieve the ambiguity of the current situation. Should this occur then the nursing education system, in its fullest extent, would reap the benefits. The focus would change from basic nursing education being part of pedagogy to being part of andragogy.

\section{SELF-DIRECTEDNESS}

Nursing education would, unlike other educational systems in South Africa, then be moving toward the concept that adult education is merely part of a life-long process of education. It would not emphasise artifical differentiations into adult and child education and would instill a sense of self-directedness, essential to nursing in modern times. This concept of self-directedness is lacking in traditional nursing education:

Traditionally, most nurses have not been exposed to the concept of personal responsibility for their own continuing education. Such a concept may be seen as a requirement for survival in society changing as rapidly as ours. Learning how to learn becomes a very significant aspect of such a concept (8 p. 50)

The development of personal responsibility and self-directedness surely lies in the nature of adult learning. Knowles (9 p. 70) has outlined these principles and they are paraphrased and summarised here. Adult learners:

- respond best to a non-threatening learning environment where there is a good student-teacher relationship

- want to assess themselves against a relevant standard to determine their education needs

- want to select their own learning experiences (to be self-directing)

- prefer a problem-oriented approach

- want to apply their new knowledge and skills immediately

- want to know they are progressing

- want to contribute (from their own reservoir of knowledge and skills) to help others learn.

Fabb (10 p. 46) notes that:

Instead of practising pedagogy, which is the art and science of teaching children, teachers of medicine should now be seeking to practice what Knowles réfers to as andragogy (andra = grown up or adult), - the art and science of helping adults to learn. By applying the principles (of adult learning), teachers can facilitate the growth and development of the learners with whom they work, and in the process, as co-learners, grow and develop themselves.

Seen in this way, adult education is the process which most helps the learners how to learn. It gives them the equipment to become self-directed learners involved in the lifelong process of education.

Teachers who work with adult learners should emphasise the principles of adult education. They should work to decrease the dependency of child learners on their teachers by:

- creating a comfortable, nonthreatening learning environment

- providing assessment opportunities to help learners diagnose their educational needs

- helping the learners plan the sequence of experiences which will meet their educational needs and produce the desired learning 
- creating conditions that will motivate the learner to learn

- selecting, with the learners, the most effective methods of producing the desired learning

- providing, with the help of the learners, the human and material resources necessary to produce the desired learning

- helping the learners measure the outcome of their learning experiences (10 p. 37-45).

It is not proposed that basic nursing education becomes self-directed learning from the first day of the education programme. It would be unrealistic to expect beginning student nurses to have any meaningful self-directedness, given the current educational systems. Selfdirected learning would be introduced gradually until, by the final year, self-directedness was fully accomplished.

The self-directed approach, like the learner-centred approach, is based on:

- identification of the major gaps between actual and specified criterion performance of skills, knowledge and attitudes, that is, determining educational needs

- awareness of the setting or system in which the learning is to take place

- selection of those educational objectives that have a high priority for a particular student's level

- selection and organisation of learning activities that will produce and maintain the desired behaviour

- evaluation of the extent to which the students have met their educational needs and the educational objectives (11 p. 114).

It can be seen that this approach can be adapted to any level of nursing education, from the most basic to the most advanced. What will vary is the amount of direction and guidance necessary for the learners.
At the basic education level the educational objectives, based on knowledge, skills and attitudes necessary for professional registration, need to be clearly stated.

Once these objectives are clearly stated then the beginning student can focus on his or her approaches to achieving them.

Knox (12 p. 72) has stated the potential benefits in organising continuing professional education on a self-directed approach:

- it provides the basis for articulation between various disciplines and between basic and continuing professional education

- it provides for planning of regional development of health manpower so that each person is encouraged to meet that region's particular health needs

- it encourages maximum utilisation of the available resources

- it facilitates the efforts of health professionals to increase their competence and improve patient care and health maintenance.

These benefits could be enhanced by introducing the adult education, self-directed approach at the basic nursing education level. On this subject Knox has noted:

During the past decade or so, many professional schools have modified their preparatory education curriculum and instructional methods in ways that have increased the likelihood that graduates will continue their education. In some instances, these modifications were deliberately made so that a basic objective of preparatory education would be the development of a questioning approach that would encourage and facilitate lifelong learning. (12 p. 72)

\section{Implementation}

A final, but crucial question remains: How would present nursing education implement fundamental rethinking of basic nursing education?
In the first instance it must be recognised that change is often threatening and slow in producing results. It is for this reason that the author believes these changes, which encompass the principles of adult learning, be introduced by innovative nurse educators at the universities - this phase has already begun at a number of universities in South Africa. First to the Diploma in Nursing Education students and then later to nursing students on degree courses. In this way generations of students' approach to learning will be gradually, but fundamentally, influenced.

If South African nurses are to meet the challenges of the future, a fundamental rethinking of nursing education is necessary. Part of this fundamental rethinking involves the switch from pedagogy to andragogy - the recognition that the student nurse is an adult learner involved in adult education. This will open up new vistas in self-directed, learnercentred learning, which will reap its greatest benefits in improved patient care by life-long learners.

\section{REFERENCES}

1. Harris, C.W. ed. Encyclopedia of Educational Re search. MacMillan New York 1960

Hely, A.S.M. New Trends in Adult Education UNESCO: Paris. 1962

3. Liveright, A.A. Education for Adults: Luxury o Necessity? in Fundamental and Adult Education. Vo 12. No. 2 UNESCO Paris. 1960

4. International Council of Nurses Special and Commirtee Reports (presented to the ICN Board of Directors and Grand Council Meetings in Frankfurt. June 1965).

5. Price, T.W. Law Notes for Nurses and Midwives in Sourh Africa. SANA: Pretoria. 1958.

6. Mellish, J.M. Theory and Method of Inservice Educe rion for Nurses. SANA Pretoria 1978 .

7. World Health Organisation Exoert Committee on Nurs World Health Organisation Exoert Commintee on Nurs
ing. Technical Report No. 437. WHO Geneva 1966 8. Cooper. S.S., Hornback. M.S. Continuing Nursing Education. Association Press New York 1973.

9. Knowles, M.S. The Modern Practice of Adull Educa tion. Association Press New York 1970

10. Fabb, W.E., Heffernan, M.W., Phillips, W.A. and Stone, P. Focus on Learning in Family Pracrice, Royal Australian College of General Practitioners Melbourne 1976 .

11. Gilbert, J.J. Educational Handhook for Health Person nel. WHO Geneva 1979

12. Knox. A.B. Life-Long Self-Directed Education. Source of reprint untraceable. 